\title{
An Archaeological Survey of a Proposed Dredge Spoil Site in Nueces County, Texas
}

\author{
Stephen L. Black \\ Department of Anthropology, Texas State University \\ Lynn Highley
}

Follow this and additional works at: https://scholarworks.sfasu.edu/ita

Part of the American Material Culture Commons, Archaeological Anthropology Commons, Environmental Studies Commons, Other American Studies Commons, Other Arts and Humanities Commons, Other History of Art, Architecture, and Archaeology Commons, and the United States History Commons

Tell us how this article helped you.

This Article is brought to you for free and open access by the Center for Regional Heritage Research at SFA ScholarWorks. It has been accepted for inclusion in Index of Texas Archaeology: Open Access Gray Literature from the Lone Star State by an authorized editor of SFA ScholarWorks. For more information, please contact cdsscholarworks@sfasu.edu. 


\section{An Archaeological Survey of a Proposed Dredge Spoil Site in Nueces County, \\ Texas}

\section{Creative Commons License}

\section{(c) (1) (8)}

This work is licensed under a Creative Commons Attribution-NonCommercial 4.0 International License 
AN ARCHAEOLOGICAL SURVEY OF A PROPOSED DREDGE

SPOIL SITE IN NUECES COUNTY, TEXAS

Stephen L. Black and Lynn Highley

Center for Archaeological Research The University of Texas at San Antonioه Archaeological Survey Report, No. 148

1985 


\section{ABSTRACT}

During December 1983, the Center for Archaeological Research, The University of Texas at San Antonio, conducted an archaeological survey of a proposed dredge spoil site in Nueces County for the Port of Corpus Christi Authority. One site (4I NU 211) was located. Artifacts included one Early Archaic dart point fragment which suggests that 41 NU 211 may date as ear1y as 4000 B.C. Limited testing is recommended to evaluate the site unless project plans are a)tered. 
TABLE OF CONTENTS

ABSTRACT .................................... i LIST OF FIGURES .......................... $i$...

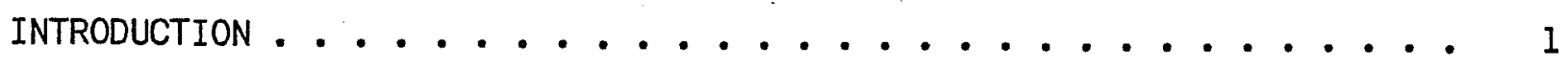

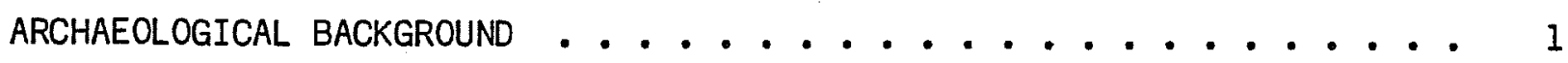

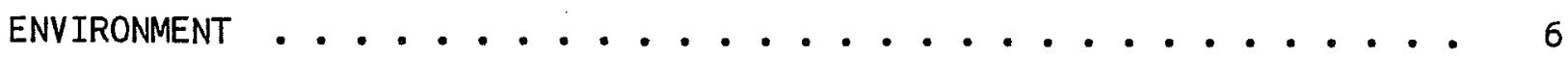

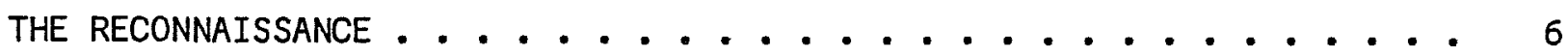
SURVEY RESULTS ...................................... 8

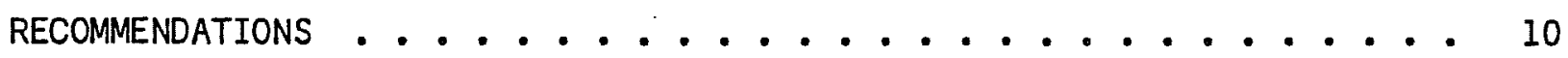

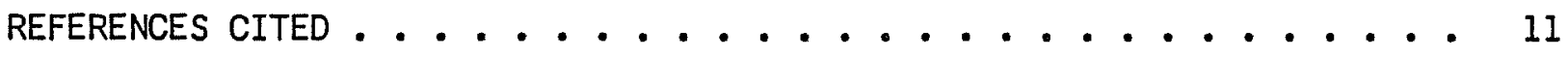

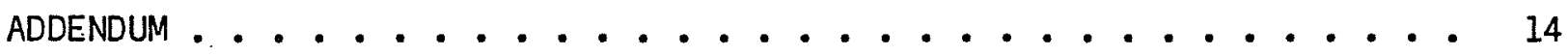

\section{LIST OF FIGURES}

1. The Surveyed Area Indicating Potentially Intact Remains of $41 \mathrm{NU} 211$. . . . . . . . . . . . . . . . . . . 2

2. Archaeological Sites in the Vicinity of the Survey Area . . . . . 5

3. Artifacts from 41 NU 2ll . . . . . . . . . . . . . . . . 9 


\section{INTRODUCTION}

During December 8-9, 1983, archaeologists from the Center for Archaeological Research (CAR), The University of Texas at San Antonio (UTSA), under contract with the Port of Corpus Christi Authority, conducted an archaeological survey of a proposed dredge spoil site in Nueces County (Fig. 1). The purpose of the survey was to determine if significant cultural resources were present on the proposed disposal tract. Field work was carried out by staff archaeologists Stephen L. Black and Lynn Highley under the direction of Dr. Thomas R. Hester, principal investigator and Jack D. Eaton, co-principal investigator.

The survey, although contracted through the Port of Corpus Christi Authority, was required by the Galveston District, Corps of Engineers (Permit No. 17078 [Withdrawn Galv.COE, A-6a]). Carolyn Good, archaeologist for the Galveston District, provided advice on the goals of the survey, reviewed the draft manuscript, and 1 ater made a visit to the survey 1 ocal ity (Good, persona 1 communication to T. R. Hester, Apri1 2, 1984).

\section{ARCHAEOLOGICAL BACKGROUND}

Previous archaeological research along the central Texas coast will be briefly summarized in this section. A short description of several sites in the immediate vicinity of the project area will also be provided.

The prehistoric remains along the central Texas coast can be divided into three broad time periods or eras. The earliest era, the Paleo-Indian period, dates between ca. 9200 B.C. and 6000 B.C. Following this is a 1ong-1 ived Archaic era which falls between ca. 6000 B.C. and A.D. 1200. The final prehistoric era is known as the Late Prehistoric and dates from ca. A.D. T200 to historic contact. Each broad time period is represented by distinctive archaeological remains.

Summaries of the archaeology of the central coastal region can be found in Campbel1 (1960), Briggs (1971), Scurlock, Lynn, and Ray (1974), Corbin (1974), Highley, Gerst1e, and Hester (1977), Highley and Hester (1980), Hester (1980a), and Carlson, Steele, and Bruno (1982).

The presence of $\mathrm{Paleo-Indian}$ archaeological remains along the coastal region was recently reviewed by Hester (1980b). The evidence is primarily limited to surface finds of distinct point types attributable to this early period of human occupation. Chandler, Knolle, and Knolle (1983) have reported the recovery of Paleo-Indian projectile points from sites along the Jim Wel1sNueces County 1 ine near the Nueces River. The 1 ack of intensive excavations of early sites has 1 imited. our understanding of such areas as paleoenvironment, geomorphology, subsistence activities, and settlement patterns.

Much of the Archaic era in the central coastal region is as poorly known as the Paleo-Indian period. Internal divisions have yet to be devised. The earliest wel1-defined cultural complex is the Aransas complex which describes Archaic manifestations along the central Texas coast, primarily in the 


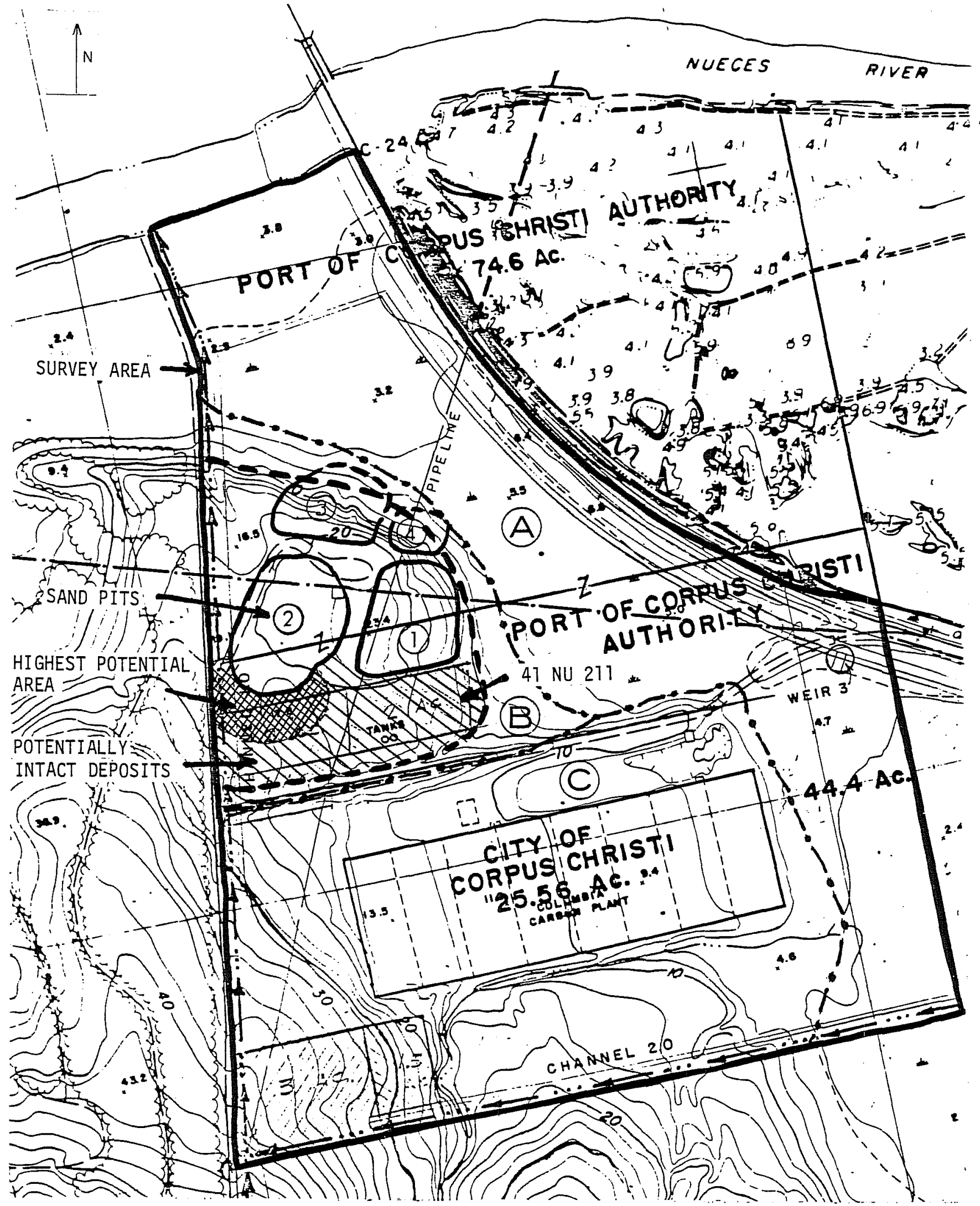

Figure 1. The Surveyed Area Indicating Potentially Intact Remains of 41 NU 211. Adapted from Corps of Engineers Map. 
Aransas Bay area (Campbel 1 1974). This complex probably dates from ca. 30002000 B.C. to A.D. 1200 (Corbin 1974). Marine resources were exploited for food and marine she11, particularly conch, were utilized as raw material for tools and ornaments. Projectile points include a variety of stemmed and unstemmed types. Other materials include drills, scrapers, bifaces, tubular stone pipes, grinding stones, abraders, and bone tools.

The Rockport complex defines the Late Prehistoric period along the central Texas coast. Sites are characterized by the occurrence of arrow points and sandy paste ceramic sherds. Marine shell arrow points may also be present. Other items include flake scrapers, marine shell ornaments, and bone artifacts (ibid.).

The Historic period is represented in aboriginal sites by the occurrence of glass trade beads and glass arrow points (Highley, Gerstle, and Hester 1977). Other sites document the presence of early Spanish, Mexican, and AngloAmerican settlements (ibid.). Nuecestown, established in 1852, is located south of the project area (Corpus Christi Caller Times 1959). Hearne's Ferry was estab 7 ished in 1867 and operated across the Nueces River northeast of Nuecestown (ibid.).

In the Nueces and Corpus Christi Bay areas of Nueces County a 1 arge number of Aransas complex and Rockport complex archaeological sites have been recorded or located. Excavations have been 1 imited to testing programs at a few sites. Many, if not most, of the recorded sites have been destroyed or severely damaged by erosion, industrial expansion, and urban growth. Important site types include she 11 middens and cemetery sites. The vast majority of these sites date to after 2000 B.C. Earlier occupations have not been documented to date. The following sites have been recorded near the project area (Fig. 2):

(1) Site 41 NU 61: open campsite/7 ithic workshop; heavy accumulation on top of hill; notes on file, TARL, Austin.

(2) Site 41 NU 154: occupation site; chert flakes, oyster/Rangia she11; notes on file, TARL, Austin.

(3) Site 41 NU 157: buried Rangia shel1 midden located on knoll overlooking Nueces River; on Tule Lake Tract; chert flakes, one scraper, pottery, and burned clay nodules observed; see Highley, Gerstle, and Hester (1977).

(4) Site 41 NU 183: shel1 midden; notes on file, TARL, Austin.

(5) Site 4l NU 185 (the A1 1 ison site): located near the A17 ison Wastewater Treatment Plant; both Late Prehistoric and Archaic components; deposits extend to over one meter in depth; pottery, marine shel1, vertebrate faunal remains, burned clay nodules, one Matamoros point, biface fragment, and 7 ithic debitage recovered; see Carlson, Steele, and Bruno (1982).

(6) Site 41 NU 186: 1 1 thic debris; oyster shel1 in elevated area between drainages; notes on file, TARL, Austin. 
Figure 2. Archaeological Sites in the Vicinity of the Survey Area.

(1) Site 41 NU 61, open campsite and 1 ithic workshop; period of occupation unknown.

(2) Site 41 NU 154, occupation site; period of occupation unknown.

(3) Site 41 NU 157, shel1 midden; Late Prehistoric component.

(4) Site 41 NU 183, shel1 midden; period of occupation unknown.

(5) Site 41 NU 185, occupation site; Late Prehistoric and Archaic components.

(6) Site 41 NU 186, 1 ithic debris and oyster she11; period of occupation unknown.

(7) McKenzie Site, Rangia shel 1 and triangular and stemmed dart points; Archaic period.

(8) Smith Site, she11 midden with one known burial and triangular dart points; Archaic period.

(9) Haas Site, she 11 midden, two known burials, dart points and other artifacts; Archaic period.

(10) Tenneco Site, occupation site; Late Prehistoric period. 
This page has been

redacted because it

contains restricted

information. 
Numerous other sites in this area have been recorded and are on file at the Texas Archeological Research Laboratory (TARL) in Austin. Several other sites in the immediate vicinity of the project area have not yet been recorded. The information on the following four sites was provided by Ed Mokry, Jr., an avocational archaeologist residing in Corpus Christi.

(7) Mckenzie Site: scatter of Rangia shel1 debris; 1 ithics include triangular and stemmed dart points.

(8) Smith Site: gradually sloping hill adjacent to Turkey Creek; part of an oyster she11 midden has been exposed; horizontal extent unknown; one flexed burial was vandalized and removed from the site; 1 ithics include Archaic triangular points.

(9) Haas Site: a Rangia she11 concentration observed on edge of borrow pit; two burials were vandalized and removed from the site; artifacts include triangular and stemmed dart points, unifacial tools, notched stone sinkers, modified conch she11; vertebrate faunal remains also present.

(10) Site on property now owned by Tenneco: Late Prehistoric occupation with Perdiz arrow points, bifaces, and Rangia shel1s.

\section{ENVIRONMENT}

The survey area is located in Nueces County which falls with in the Tamaulipan Biotic Province (BTair 1950). The climate is described as subhumid (Thornthwaite 1931) with average rainfal1 averaging less than 30 inches (Carlson, Steele, and Bruno 1982). Soi 7 information is provided by the U.S. Department of Agriculture (1965), and information regarding vegetation can be found in Jones (1975) and Gould (1975).

The mainland of Nueces County is part of a nearly level coastal plain (U.S. Department of Agriculture 1965). The Nueces River flows along the northern edge of the county and empties into Nueces Bay. The steepest slopes of the river valley occur near the head of Nueces Bay (Carlson, Steele, and Bruno 1982).

Additional information regarding environmental conditions can be found in Brown et a1. (1976), Shafer and Bond (n.d.), and Carlson, Steele, and Bruno (1982).

\section{THE RECONNAISSANCE}

An intensive archaeological survey was carried out over approximately 113 acres contained within the project area. This area was divided into three sections for survey purposes (Fig. 1). These sections are described below.

Three factors governed the survey procedures in each survey section: (1) ground visibility, (2) site potential, and (3) previous disturbances. Dense vegetation covered some parts of the survey area and effectively masked 
all the ground surface. The low mud flat part of the survey area is with in the modern active floodplain of the Nueces River and is periodically inundated and altered by the flooding Nueces River. The potential for archaeological sites in this area is zero. Much of the project area has been destroyed or severely disturbed by construction, removal of sand, and il legal dumping of trash. Thus, the survey was concentrated in parts of the survey area that had some site potential and archaeological visibility. The entire survey area was walked over despite the obvious futility of searching for cultural remains in many parts of the area.

\section{Section A}

Section A encompasses the active Nueces River floodplain and is characteristically termed "mud flats." This area represents the eastern part of the survey area. This section was the only part of the project area where vegetation did not obscure visibility. However, the construction of the rail road located along the eastern edge of the project area and the dumping of concrete refuse from the Columbia Carbon Plant have previously impacted a part of Section $A$, and as stated previous $1 y$, this area is periodically inundated by the flooding Nueces River. Although the possibility of finding cultural remains in this area was unlikely, the area was surveyed in a zigzag pattern. Nothing of cultural significance was noted.

\section{Section B}

Section B includes the distinct hill located in the northwestern part of the survey area (Fig. 1). The hill is a Pleistocene terrace remnant of the Nueces River. The archaeological site potential of Section B was very high since sites previously recorded in this part of Nueces County general $1 \mathrm{y}$ occur at higher topographic locations. The hilltop area, however, has been severely impacted in recent times. Four 7 arge sand pits are present, and this area has been used as an $i l l e g a l$ dumping ground for everyday trash and abandoned vehicles.

The upper perimeter and walls of the sand pits did provide excel lent archaeological visibility and were carefully examined for cultural materials. Evidence consisting of an Early Archaic dart point fragment, one unifacial tool, numerous flakes, marine she 11 fragments, and fish remains indicate an archaeological site is present on the hilltop.

\section{Section C}

The third section of the survey is located in the southwestern part of the project area and encompasses the previous location of the Columbia Carbon Plant. This entire area contains brushy vegetation resulting in poor ground visibility. Several smal1 tracts of 1 and are privately owned in Section C. These tracts are fenced and covered with houses, sheds, and animal pens. These privately owned tracts were not examined. The remains of the carbon 
plant were located. This area has been severely impacted due to construction, maintenance, and removal of the plant.

A 7 though the survey of Section $C$ was hampered by previous impact, dense vegetation, and privately owned tracts, several roads and a pipeline crossed the area offering some ground visibility. These areas were careful1y examined. Only two chert flakes were observed. Based on known site locations north and south of the project area, it is 1 ikely that archaeological sites are or were present upslope (south and west) of Section $C$ (out of the project area). The flakes observed in Section C probab 1 y represent the outer fringe of an as yet undefined, unrecorded archaeological site. The low density of cultural material observed within Section C suggests that significant cultural resources are not present.

\section{SURVEY RESULTS}

Section $B$ is the on $7 y$ part of the survey area that may contain a significant archaeological resource. Investigation of the hilltop revealed the presence of numerous chert $f 1$ akes and one smal1 chert core, evidence of prehistoric stone tool manufacturing activities. The southern edge of Sand Pit 2 revealed many $f l a k e s$, one unifacial tool ( $F i g .3, a$ ), a dart point fragment (Fig. 3,b), marine shel1 fragments, and fish remains. The entire hil1top area as shown in Figure 1 was recorded as archaeological site 41 NU 211.

The presence of the dart point fragment is particularly significant. It can tentatively be identified as the distinctive barb fragment of an Andice or Bel1 point, Early Archaic dart point forms. Prewitt (1983) has recentiy defined the Andice dart point and discussed the differences between Andice and Bel1 point types. Andice points have long rectangular stems and prominent barbs that extend to the basal edge. The overall point is quite 1 arge--width, $42 \mathrm{~mm}$; 1 ength, $106 \mathrm{~mm}$ (ibid.). Bel1 points may be somewhat smaller in size, have rectangular to expanding stems, and have strongly barbed blades (Chandler 1983). According to Prewitt (1983), the two types intergrade in morphological characteristics. Both point types are Early Archaic types (4050-3050 B.C.) (ibid.). Geographic distribution includes central Texas, across the Gulf Coastal Plain to the Victoria-Corpus Christi area (Prewitt 1983). Be11 points have been reported from the southeastern part of Texas in San Patricio County (Chandier 1983), McMulien County (Woerner and Highley 1983), and Victoria County (Fox and Hester 1976). A71 of these instances represent surface finds--an intact Early Archaic component containing Be11 or Andice points has yet to be excavated in this part of Texas.

The presence of an Early Archaic dart point fragment suggests that 41 NU 211 may date as early as 4000 B.C. Later components may also be present although no definite evidence was found. If buried intact deposits dating to the Early Archaic are present south of Sand Pit 2 then the site is a very significant archaeological resource.

Despite careful examination of the eroded sand pit wal1s, the precise area from which the materials were eroding could not be determined. Cultural 

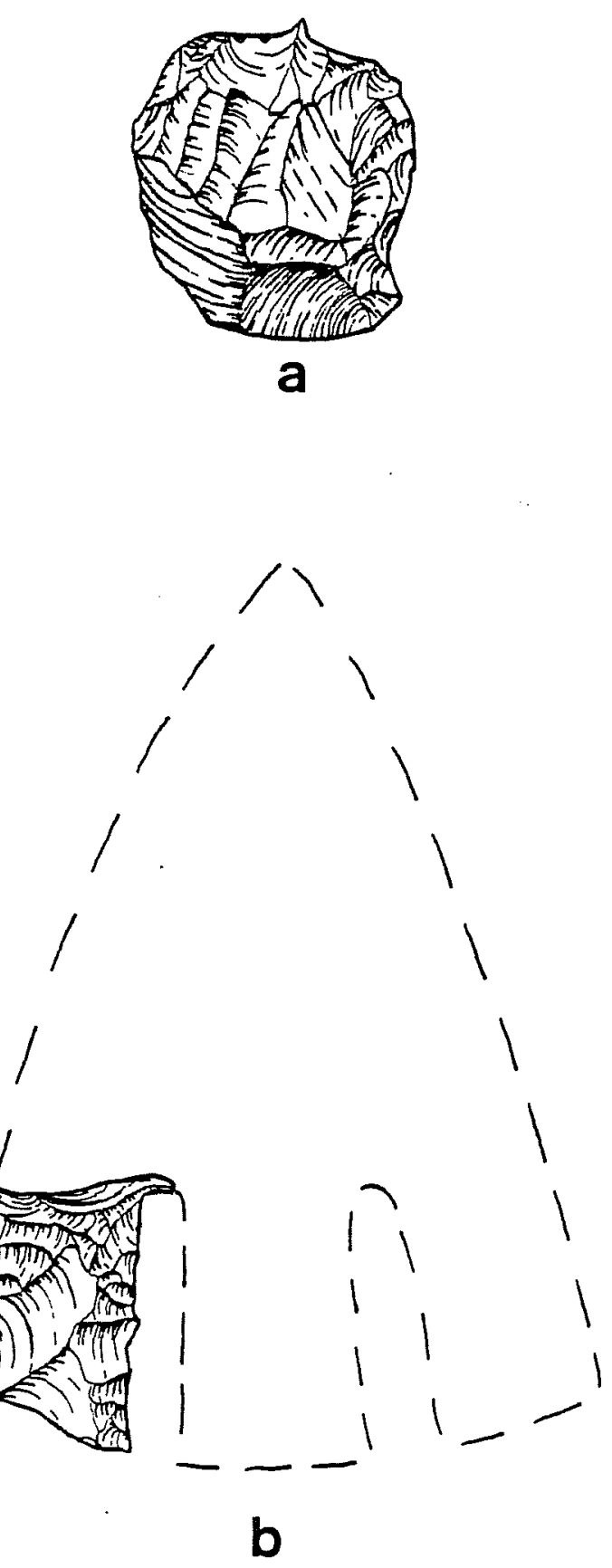

Figure 3. Artifacts from 41 NU 211. a, beaked unifacial too 1; b, barb from Andice or Bel1 dart point with projected outline of complete specimen. Il lustrated actual size. 
materials appeared to be restricted to the upper part of the profile but could be buried as much as a meter below the original ground surface. In the unexcavated areas between the sand pits, the original surface was covered with a $30-75 \mathrm{~cm}$ thick overburden. The overburden appeared to be sand removed from the pits.

\section{RECOMMENDATIONS}

The proposed disposal project will severely impact the entire project area as currently planned. Therefore, it is recommended that the southern part of site 41 NU 211 in Section B (Fig. 1) be tested to determine if intact cultural deposits are present. If an intact Early Archaic component can be documented then the site is a significant archaeological resource and would qualify for eligibility to the National Register of Historic Places. This work would be done in compliance with the National Historic Preservation Act of 1966 (as amended), Section 106, 36CFR800, and Executive Order 11593. Alternatively, if testing failed to document intact cultural deposits then the site would not be considered significant. Thus, 1 imited testing is recommended to evaluate 41 NU 211 unless the project p 1 ans are altered. Conflict with the potential archaeological resource could be avoided by leaving the southern hilltop area intact (i.e., avoiding al 1 construction in this area). If the potential site area were avoided then testing would not be required.

The sensitive part of the project area that may contain significant intact archaeological deposits is shown in Figure 1. As is obvious, most of the sensitive area is currently privately owned. This area is fenced off and covered with houses, sheds, animal pens, and modern refuse. This presents a problem as it may be very difficult, if not impossible, to evaluate the archaeological site without testing on the private property. Testing the private property will be difficult given the clutter of structures and refuse. Testing could be restricted to the few remaining intact parts of the hil 11 on city-owned property. However, the absence of intact deposits in these areas would not rule out the possibility that intact deposits are present on the private property south of Sand Pit 2.

Two forms of testing are recommended: backhoe trenching and hand testing. Assuming that access was granted and that the private property south of Sand Pit 2 was cleared of al1 structures, fences, and refuse the testing program would require a day of work with the backhoe followed by four days of hand testing. A crew of four should be able to test the site in one work week. The recommended testing should enable archaeologists to effectively evaluate the nature of the archaeological deposits. If intact deposits of a significant nature are uncovered then the site would have to be either avoided or mitigated. It is entirely possible, if not probable, that significant intact deposits are not present. If this is the case, then the testing program would provide archaeological clearance for the project area.

Based on the reconnaissance, no potential conflict with cultural resources was documented in the remaining project area. Due to the problems of dense vegetation, previous impact, and private property noted previously, it is 
possible that significant resources are present but not observed. Thus, it is recommended that if archaeological resources are discovered during the proposed project that al1 work be immediately halted and appropriate state and federal authorities (Corps of Engineers; Texas Historical Commission) be contacted.

\section{REFERENCES CITED}

Blair, W. F.

1950 The Biotic Provinces of Texas. The Texas Journal of Science $2(1): 93-115$.

Briggs, A. K.

1971 Archeological Resources in the Texas Coastal Low 1 ands and Littora 1. Texas Historical Survey Committee and Texas Water Development Board, Austin, Texas.

Brown, L. F., J r., J. L. Brewton, J. H. McGowen, T. J. Evans; W. L.. Fisher, and C. G. Groat

1976 Environmental Geologic Atlas of the Texas Coastal Zone-Corpus Christi Area. Bureau of Economic Geology, University of Texas at Austin.

Campbe11, T. N.

1947 The Johnson Site: Type Site of the Aransas Focus of the Texas Coast. Bulletin of the Texas Archeological and Paleontological Society 18:40-75.

1960 Archeology of the Central and Southern Sections of the Texas Coast. Bul1etin of the Texas Archeological Society 29:145176 .

Carison, D. L., D. G. Steele, and H. L. Bruno

1982 Archeological Investigations at the A11 ison Site (41 NU 185), Nueces County, Texas. Texas A\&M University, Archeologica 1 Research Laboratory, Reports of Investigations 1.

Chandler, C. K.

1983 Notes On some Be11 Points From San Patricio County, Texas. La Tierra 10(3):7-10.

Chandler, C. K., F. Knolle, and M. M. Knolle

1983 Paleo-Indian Projectile Points From Jim Wel $1 \mathrm{~s}$ and Nueces Counties, Texas. La Tierra 10(2):23-27. 
Corbin, J. E.

1974 A Model for Cultural Succession for the Coastal Bend Area of Texas. Bulletin of the Texas Archeological Society 45:29-54.

Corpus Christi Caller Times

1959 Diamond Jubilee Historical Edition, January 18, 1959.

Fox, A. A. and T. R. Hester

1976 An Archaeological Survey of Coleto Creek, Victoria and Goliad Counties, Texas. Center for Archaeological Research, The University of Texas at San Antonio, Archaeological Survey Report 18.

Gould, F.

1975 Texas Plants: A Check 7 ist and Ecological Summary. Texas Agricultural Experiment Station MP-585.

Hester, T. R.

1980a Digging Into South Texas Prehistory. Corona Publishing Company, San Antonio, Texas.

1980b A Survey of Paleo-Indian Archaeological Remains Along the Texas Coast. In Papers on the Archaeology of the Texas Coast, edited by L. Highley and T. R. Hester:1-12. Center for Archaeological Research, The University of Texas at San Antonio, Special Report 11.

Highley, L. and T. R. Hester, editors

1980 Papers on the Archaeology of the Texas Coast. Center for Archaeological Research. The University of Texas at San Antonio, Special Report 11.

Highley, L., A. Gerstle, and T. R. Hester

1977 An Archaeological and Historical Assessment of the Tule Lake Tract, Nueces County, Texas. Center for Archaeological Research, The University of Texas at San Antonio, Archaeological Survey Report 27.

Jones, F. B.

1975 Flora of the Texas Coastal Bend. Welder Wildlife Foundation, Contr. B-6. 
Prewitt, E. R.

1983 Andice: An Early Archaic Dart Point Type. La Tierra 10(3):16.

Scurlock, D., W. M. Lynn, and R. T. Ray

1974 Archeological Assessment, Padre Is 1 and National Seashore. Office of the State Archeologist. Special Report 11.

Shafer, H. J. and C. Bond

n.d. An Archeological and Historical Review of the Central Texas Coast. Manuscript on file at the Archeology Research Laboratory, Texas A\&M University, Coll lege Station.

Thornthwaite, C. W.

1931 The Climates of North America According to a New Classification. Geographical Review 21:633-655.

U.S. Department of Agriculture

1965 Soil Survey, Nueces County. Soil Conservation Service in Cooperation with Texas Agricultural Experiment Station.

Woerner, M. C. and L. Hightey

1983 The Brom ley F. Cooper Collection of Pre-Archaic and Archaic Dart Points from McMulien County. La Tierra 10(1):3-28. 


\section{ADDENDUM}

On February 15, 1985, the Center for Archaeological Research received a copy of a six-page manuscript (with accompanying maps and field notes) detailing the on-site visit by archaeologists from Corps of Engineers, Galveston District. We have not had the opportunity to integrate their findings into this present report. However, it should be noted that additional artifacts were collected from 41 NU 21l, including a triangular dart point that may be of Early Archaic date. In the Corps' report, it is further noted that only about 20\% of this site remains intact, most of its destruction having resulted from gravel quarrying operations. The site is still potentialiy eligible for nomination to the National Register of Historic Places.

For further information on the Corps of Engineers study, consult

Good, Carolyn

n.d. Cultural Resource Assessment, Dept. of Army Permit Application No. 17078. Port of Corpus Christi Authority, App 1 icant Nueces County, Texas. Manuscript on file, Galveston District, Corps of Engineers. 